\title{
Nachruf
}

\section{Nachruf auf HR Mag. Bruno Bauer, Herausgeber von ABI Technik}

http://doi.org/10.1515/abitech-2021-0001

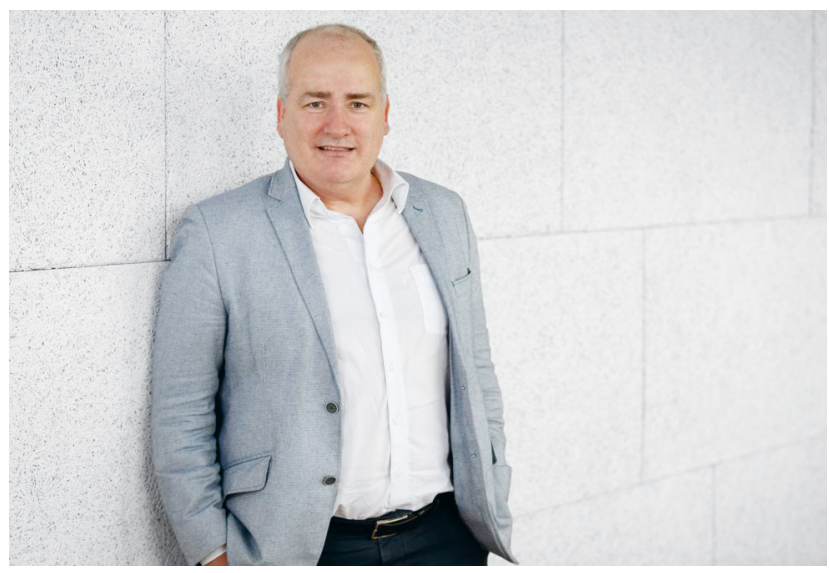

Foto: derknopfdrücker
Bruno Bauer gehörte seit dem Jahr 2018 dem Herausgeberteam von ABI Technik an. Er brachte sich sofort mit voller Energie als Herausgeber ein und bestimmte fortan die inhaltliche Ausrichtung von ABI Technik wesentlich mit. Ein Interessensschwerpunkt lag dabei auf der Frage der Umsetzung von Open Science.

Als langjähriger Direktor der Universitätsbibliothek der MedUni Wien war Bruno Bauer ein wegen seiner Fachkompetenz und seines kooperativen Stils geschätzter Kollege. Mit einer Vielzahl von Aufgaben und Funktionen mag es ihm nicht immer leichtgefallen sein, in den Abendstunden oder am Wochenende neben umfangreicher eigener publizistischer Tätigkeit Beiträge von anderen durchzusehen oder neue Publikationen anzustoßen. Er war einer der publizistisch aktivsten und meistgelesenen Bibliothekare, und als Herausgeber kam ihm sein enormer Überblick über die neusten Entwicklungen im Bibliothekswesen besonders zugute. Sein Wissen teilte er großzügig.

ABI Technik verdankt Bruno Bauers unermüdlicher Tätigkeit als Herausgeber vielgelesene und weit rezipierte Beiträge. Die ihm eigene fachlich präzise und menschlich kultivierte Art machte es jederzeit zu einer Freude, mit ihm in Kontakt zu stehen.

Bruno Bauer hinterlässt eine große Lücke. Mit ihm hat das deutschsprachige Bibliothekswesen einen wichtigen Gestalter und einen besonderen Menschen verloren. Gern hätten wir auch bei ABI Technik noch viel länger mit ihm zusammengearbeitet. Wir gedenken seiner mit besonderer Dankbarkeit.

Die Herausgeberinnen und Herausgeber von ABI Technik Claudia Heyer und Florian Hoppe von De Gruyter 